\title{
Visible-Light-Mediated Generation of Nitrile Oxides for the Photoredox Synthesis of Isoxazolines and Isoxazoles
}

DOI:

10.1039/C6CC06029C

Document Version

Accepted author manuscript

Link to publication record in Manchester Research Explorer

\section{Citation for published version (APA):}

Svejstrup, T., Zawodny, W., Douglas, J. J., Bidgelli, D., Sheikh, N. S., \& Leonori, D. (2016). Visible-Light-Mediated Generation of Nitrile Oxides for the Photoredox Synthesis of Isoxazolines and Isoxazoles. Chemical

Communications- Royal Society of Chemistry. https://doi.org/10.1039/C6CC06029C

\section{Published in:}

Chemical Communications- Royal Society of Chemistry

\section{Citing this paper}

Please note that where the full-text provided on Manchester Research Explorer is the Author Accepted Manuscript or Proof version this may differ from the final Published version. If citing, it is advised that you check and use the publisher's definitive version.

\section{General rights}

Copyright and moral rights for the publications made accessible in the Research Explorer are retained by the authors and/or other copyright owners and it is a condition of accessing publications that users recognise and abide by the legal requirements associated with these rights.

\section{Takedown policy}

If you believe that this document breaches copyright please refer to the University of Manchester's Takedown Procedures [http://man.ac.uk/04Y6Bo] or contact uml.scholarlycommunications@manchester.ac.uk providing relevant details, so we can investigate your claim.

\section{OPEN ACCESS}




\section{Accepted Manuscript}

This article can be cited before page numbers have been issued, to do this please use: T. Svejstrup, W. Zawodny, J. J. Douglas, D. Bidgelli, N. S. Sheikh and D. Leonori, Chem. Commun., 2016, DOI:
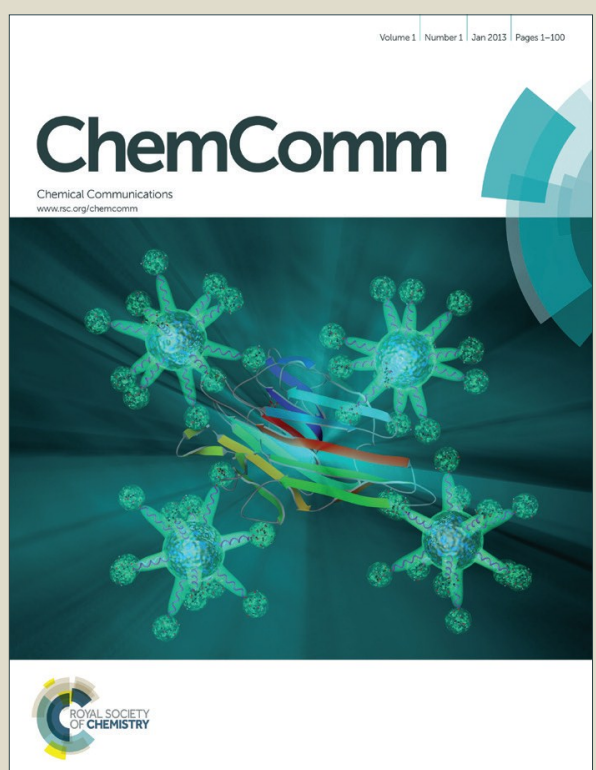

This is an Accepted Manuscript, which has been through the Royal Society of Chemistry peer review process and has been accepted for publication.

Accepted Manuscripts are published online shortly after acceptance, before technical editing, formatting and proof reading. Using this free service, authors can make their results available to the community, in citable form, before we publish the edited article. We will replace this Accepted Manuscript with the edited and formatted Advance Article as soon as it is available.

You can find more information about Accepted Manuscripts in the Information for Authors.

Please note that technical editing may introduce minor changes to the text and/or graphics, which may alter content. The journal's standard Terms \& Conditions and the Ethical guidelines still apply. In no event shall the Royal Society of Chemistry be held responsible for any errors or omissions in this Accepted Manuscript or any consequences arising from the use of any information it contains. 


\section{COMMUNICATION}

\section{Visible-Light-Mediated Generation of Nitrile Oxides for the Photoredox Synthesis of Isoxazolines and Isoxazoles}

MkderReceived 00th January 20xx Accepted 00th January 20xx

DOI: $10.1039 / x 0 x \times 00000 x$
Thomas D. Svejstrup, ${ }^{a}+$ Wojciech Zawodny,${ }^{a}+$ James J. Douglas, ${ }^{b}$ Damon Bidgelli, ${ }^{a}$ Nadeem S. Sheikh, ${ }^{c}$ and Daniele Leonori ${ }^{\mathrm{a} *}$

www.rsc.org/ChemCommun

Visible-light photoredox catalysis enables the synthesis of biologically relevant isoxazolines and isoxazoles from hydroxyimino acids. The process shows broad functional group compatibility and mechanisitic and computational studies support a visible-light-mediated generation of nitrile oxides by two sequential oxidative single electron transfer processes.

Small nitrogen-containing heterocycles are among the most important building blocks for the synthesis of biologically active molecules. ${ }^{1}$ Among this class of compounds, isoxazolines and isoxazoles are particularly relevant as they form the core structure of many currently used therapeutic agents, veterinary products and agrochemicals (Scheme $1 \mathrm{~A}){ }^{2}$ The continued interest in isoxazolines and isoxazoles is not limited to their biological properties but equally their routine use as masked 1,3-dicarbonyl functionalities. ${ }^{3}$ Generally, these heterocycles are assembled via a [3+2]-dipolar cycloaddition of nitrile oxides, themselves typically prepared from sometimes unstable hydroxymoyl chlorides, ${ }^{4}$ or by the dehydration of nitroalkanes ${ }^{5}$ under frequently harsh conditions. ${ }^{2 c, 6}$ Given the relevance of isoxazolines and isoxazoles in organic and medicinal chemistry, the development of new methods able to access them from simple and stable starting materials, and under mild reaction conditions is an important endeavour.

Visible light-photoredox catalysis has now been established as a powerful technique to perform single-electron transfer $(\mathrm{SET})^{7}$ reactions under very mild and user-friendly conditions. ${ }^{8}$ While exploited for the formation of many $\mathrm{C}-\mathrm{C}$ and $\mathrm{C}-\mathrm{X}(\mathrm{X}=$ heteroatom) bonds, photoredox catalysis has found a somewhat limited application in the synthesis of small ring heterocycles ${ }^{9}$ via dipolar cyloaddition. ${ }^{10}$ Xiao and co-workers

\footnotetext{
a. School of Chemistry, University of Manchester, Oxford Road, Manchester, M13 9PL, UK.

. AstraZeneca, Silk Road Business Park, Macclesfield SK10 2NA, United Kingdom c. Department of Chemistry, Faculty of Science, King Faisal University, Al-Ahsa 31982, Saudi Arabia.

Email: daniele.leonori@manchester.ac.uk.

† These authors contributed equally.

Electronic Supplementary Information (ESI) available: Full experimental and computational details and characterisation. See DOI: 10.1039/x0xx00000x
}

developed a method for the synthesis of pyrroles and oxazoles involving the oxidation of $2 \mathrm{H}$-azirines to aza-allenyl radical cations. ${ }^{11}$ Rueping ${ }^{12}$ and $X_{\text {Xiao }}{ }^{13}$ reported the SET oxidation of tetrahydroisoquinolines as a key step in the generation of azomethine ylids and the subsequent preparation of pyrroles derivatives. Yoon has developed the photoredox cycloaddition of phenols and cyclopropyl ketones to access dihydrobenzofurans and saturated 5-membered ring heterocycles. ${ }^{14}$ Furthermore, Tan, ${ }^{15}$ Bissember $^{16}$ and Zhang ${ }^{17}$ have recently disclosed the formation of $\alpha$-amino radicals and their use in Povarov reactions. In this communication we describe the development of the first visible-light-mediated method for the generation of nitrile oxides and their utility in the synthesis of isoxazolines and isoxazoles (Scheme 1B).

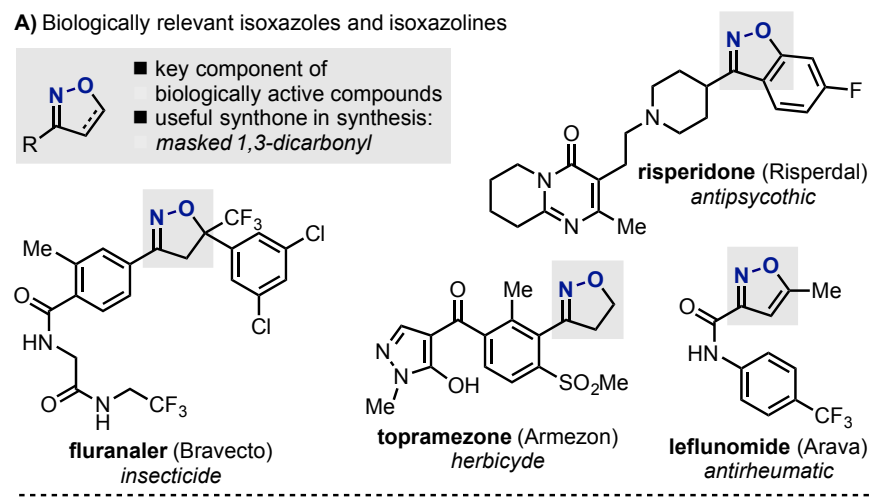

B) This work: visible-light-mediated generation of nitrile oxides

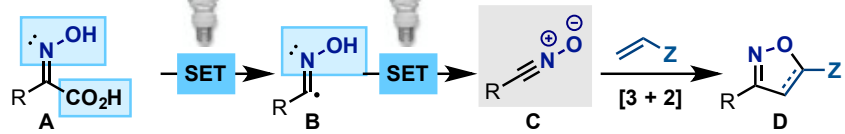

Scheme 1. Isoxazoles and isoxazolines and current work.

At the outset of our work, we were keen to identify a class of nitrile oxide precursors that would be (i) easy-to-make, (ii) bench stable, and (iii) that would offer high structural modularity. We reasoned that hydroxyimino acids A would 
represent an ideal starting point owing to their simple preparation via condensation of $\alpha$-ketoacids with hydroxylamine (Scheme 1B). Mechanistically, we were intrigued by the fact that these substrates contain two redox active functionalities (the carboxylic acid group and the $\mathrm{N}-\mathrm{OH}$ system) $)^{6 c}$ that can sequentially serve as a duel photoredox electrophore en route to the nitrile oxide. According to our design plan, photoredox SET decarboxylation ${ }^{18}$ would produce the acyl-like radical $\mathbf{B}$, that upon a second SET oxidation would form the nitrile oxide $\mathbf{C}$. Subsequent in situ [3+2] cycloaddition with a dipolarophile would furnish the targeted isoxazoline $\mathbf{D}$. To assess our hypothesis, we started by investigating the reaction of 1a and styrene using various photoredox catalysts and terminal oxidants. As illustrated in Scheme 2, we were pleased to find that using eosin $\mathrm{Y}$ as the photoredox catalyst, $\mathrm{NaHCO}_{3}$ as the base and air as the terminal oxidant in DMF under visible-light irradiation, $\mathbf{2 a}$ was obtained in $6 \%$ yield (entry 1 ). We then evaluated different oxidants and found that by employing oxone the yield was improved to $38 \%$ (entries $2-$ 5). By using $\mathrm{Ru}(\mathrm{bpy})_{3} \mathrm{Cl}_{2}$ as the photoredox catalyst, the efficiency of the process was further improved and $\mathbf{2 a}$ was isolated in $75 \%$ yield (entry 7). Control experiments and light ON-OFF reaction analysis confirmed the requirement for light, photocatalyst and oxone. ${ }^{19}$ Other bases, solvents and photoredox catalysts were evaluated but they generally provided 2a with lower efficiency (entries 12-16).

\begin{tabular}{|c|c|c|c|c|c|c|}
\hline \multirow[b]{2}{*}{ Entry } & \multicolumn{4}{|c|}{ 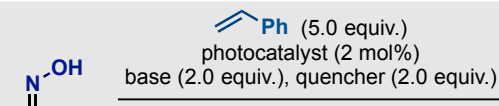 } & \multicolumn{2}{|l|}{$\overbrace{2 a}^{N-O}$} \\
\hline & Photocatalyst & Base & Quencher & Solvent & Light & Yield (\%) \\
\hline 1 & EY & $\mathrm{NaHCO}_{3}$ & air & DMF & $30 \mathrm{~W}$ CFL & 6 \\
\hline 2 & EY & $\mathrm{NaHCO}_{3}$ & $\mathrm{BrCCl}_{3}$ & DMF & green LEDs & 12 \\
\hline 3 & EY & $\mathrm{NaHCO}_{3}$ & 3 & DMF & green LEDs & traces \\
\hline 4 & EY & $\mathrm{NaHCO}_{3}$ & 4 & DMF & green LEDs & traces \\
\hline 5 & EY & $\mathrm{NaHCO}_{3}$ & oxone & DMF & green LEDs & 38 \\
\hline 6 & $\mathrm{Ru}(\mathrm{bpy})_{3} \mathrm{Cl}_{2}$ & $\mathrm{NaHCO}_{3}$ & oxone & DMF & $30 \mathrm{~W}$ CFL & 41 \\
\hline 7 & $\mathrm{Ru}(\mathrm{bpy})_{3} \mathrm{Cl}_{2}$ & $\mathrm{NaHCO}_{3}$ & oxone & DMF & blue LEDs & 75 \\
\hline 8 & - & $\mathrm{NaHCO}_{3}$ & oxone & DMF & blue LEDs & traces \\
\hline 9 & $\mathrm{Ru}(\mathrm{bpy}){ }_{3} \mathrm{Cl}_{2}$ & $\mathrm{NaHCO}_{3}$ & oxone & DMF & - & traces \\
\hline 10 & $\mathrm{Ru}(\mathrm{bpy})_{3} \mathrm{Cl}_{2}$ & $\mathrm{NaHCO}_{3}$ & oxone & $\mathrm{MeCN}$ & blue LEDs & 11 \\
\hline 11 & $\mathrm{Ru}(\mathrm{bpy})_{3} \mathrm{Cl}_{2}$ & $\mathrm{NaHCO}_{3}$ & oxone & DMSO & blue LEDs & traces \\
\hline 12 & $\mathrm{Ru}(\mathrm{bpy})_{3} \mathrm{Cl}_{2}$ & $\mathrm{Cs}_{2} \mathrm{CO}_{3}$ & oxone & DMF & blue LEDs & 31 \\
\hline 13 & $\mathrm{Ru}(\mathrm{bpy})_{3} \mathrm{Cl}_{2}$ & $(i-\mathrm{Pr})_{2} \mathrm{NEt}$ & oxone & DMF & blue LEDs & 18 \\
\hline 14 & $\operatorname{Ir}(\mathrm{ppy})_{3}$ & $\mathrm{NaHCO}_{3}$ & oxone & DMF & blue LEDs & 16 \\
\hline 15 & 5 & $\mathrm{NaHCO}_{3}$ & oxone & DMF & $30 \mathrm{~W}$ CFL & 3 \\
\hline 16 & 6 & $\mathrm{NaHCO}_{3}$ & oxone & DMF & $30 \mathrm{~W}$ CFL & 63 \\
\hline & 5 & 6 & & & $\mathrm{Me}$ & \\
\hline
\end{tabular}

Scheme 2. Optimization of the visible-light-mediated synthesis of isoxazoline $\mathbf{2 a}$ from hydroxyimino acid $\mathbf{1 a}$.

With the optimised reaction conditions in hand, we evaluated the scope of the process using hydroxyimino acid $1 \mathbf{a}$ and a series of differentially para-substituted styrene partners. The reaction tolerated both electron rich and electron withdrawing substituents as shown by the formation of substrates $\mathbf{2 a -} \mathbf{a}$ in good to high yields. We then expanded the scopentotienevinytnaphthalene and 2-vinyl-pyridine that sucdesiffurf $/$ provilear $2 \mathrm{~h}$ and $\mathbf{2} \mathbf{i}$ in moderate and high yields respectively. We were keen to explore the use of Michael acceptors as dipolarophiles in order to (i) evaluate the functional group compatibility of our process as well as (ii) obtaining molecules with handles for further manipulation. Pleasingly this photoredox manifold allowed reaction with a broad range of substrates such as carbonyl-based Michael acceptors (2j, 2k, 2m), acrylonitrile (2l) and a redox active vinyl-sulfone (2n). ${ }^{20}$ Alkyl substituted olefins could also be engaged in the reaction (20) as well as disubstituted olefins ( $\mathbf{2 p}$ and $\mathbf{2 q}$ ). Both electron rich and electron poor cyclic dipolarophiles reacted well allowing access to bicyclic frameworks ( $2 r$ and $2 s)$. The formation of $2 s$ is noteworthy as the excited state of many photoredox catalysts are able to cleave highly electron rich functionalities by oxidative SET. ${ }^{21}$ This methodology was also successful when gem-di-substituted olefins were employed as shown by the formation of $\mathbf{2 t}$ and $\mathbf{2} \mathbf{u}$ that contain a quaternary stereocentre and $2 \mathbf{v}$ that shows that this method is suitable for the preparation of spirocycles By using alkynes, the aromatic isoxazoles $\mathbf{2} \mathbf{w}$ and $\mathbf{2} \mathbf{x}$ were obtained in moderate yield. Finally we extended our protocol using hydroxyimino acids $\mathbf{1 b}$ and $\mathbf{1 c}$ that generated benzylic and alkyl nitrile oxides and formed products $\mathbf{2 y}$ and $\mathbf{2 z}$ in good yields.

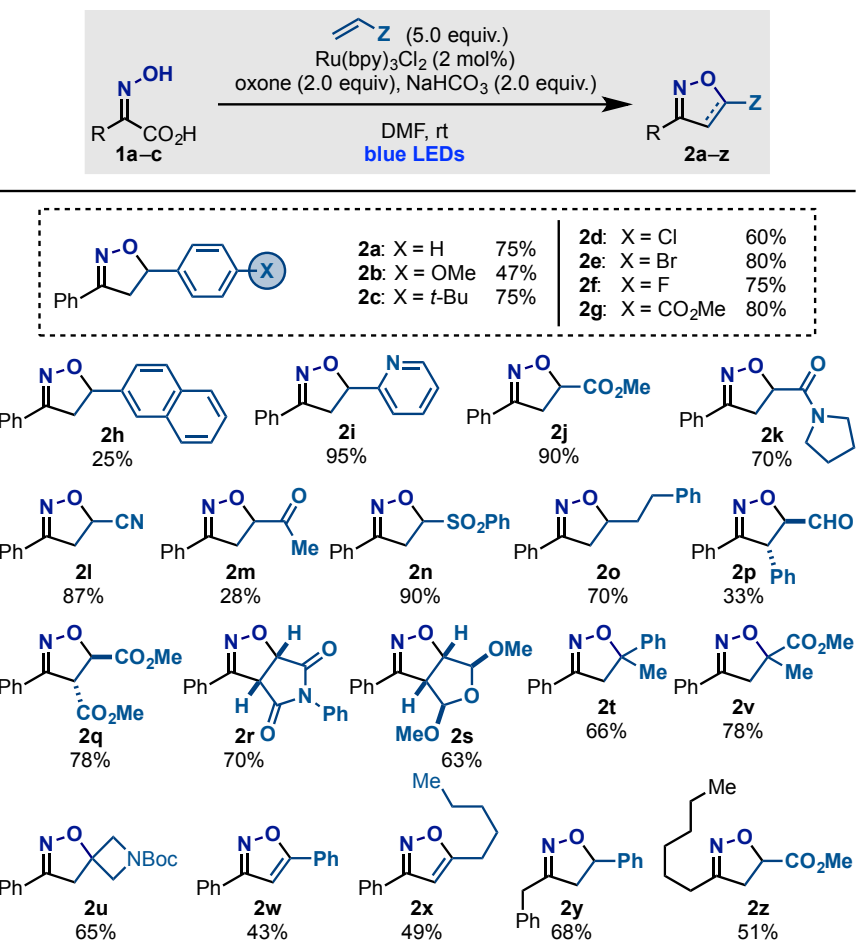

Scheme 3. Scope of the visible-light-mediated synthesis of isoxazolines and isoxazoles.

Having evaluated the scope of this photoredox transformation we decided to perform mechanistic and computational studies to investigate our proposed mechanism. As illustrated in Scheme 5, upon visible-light irradiation, the excited state of $\mathrm{Ru}(\mathrm{bpy})_{3}{ }^{2+}\left[{ }^{*} \mathrm{Ru}(\mathrm{bpy})_{3}{ }^{2+}\right]$ could be oxidised by oxone to 
$\mathrm{Ru}(\mathrm{bpy})_{3}{ }^{3+}$, a very strong oxidant $\left[\mathrm{E}_{1 / 2}{ }^{\text {red }}=1.29 \mathrm{~V}\right.$ (vS SCE)], that can promote the oxidative decarboxylation of $1 a^{-18 a}$ This event would deliver the acyl-like radical $\mathbf{B}$ and close the photoredox cycle. We have excluded a direct oxidative decarbocylation of $1 a^{-}$by $\left[{ }^{*} R u(b p y){ }_{3}{ }^{2+}\right]$ owing to (i) the high oxidation potential of $1 a^{-}\left[E_{1 / 2}{ }^{o x}=1.31 \mathrm{~V}\right.$ (vs SCE)] and (ii) Stern-Volmer analysis that revealed oxone and not $1 \mathbf{a}^{-}$to quench $\left[{ }^{*} \mathrm{Ru}(\mathrm{bpy})_{3}{ }^{2+}\right]^{19}$

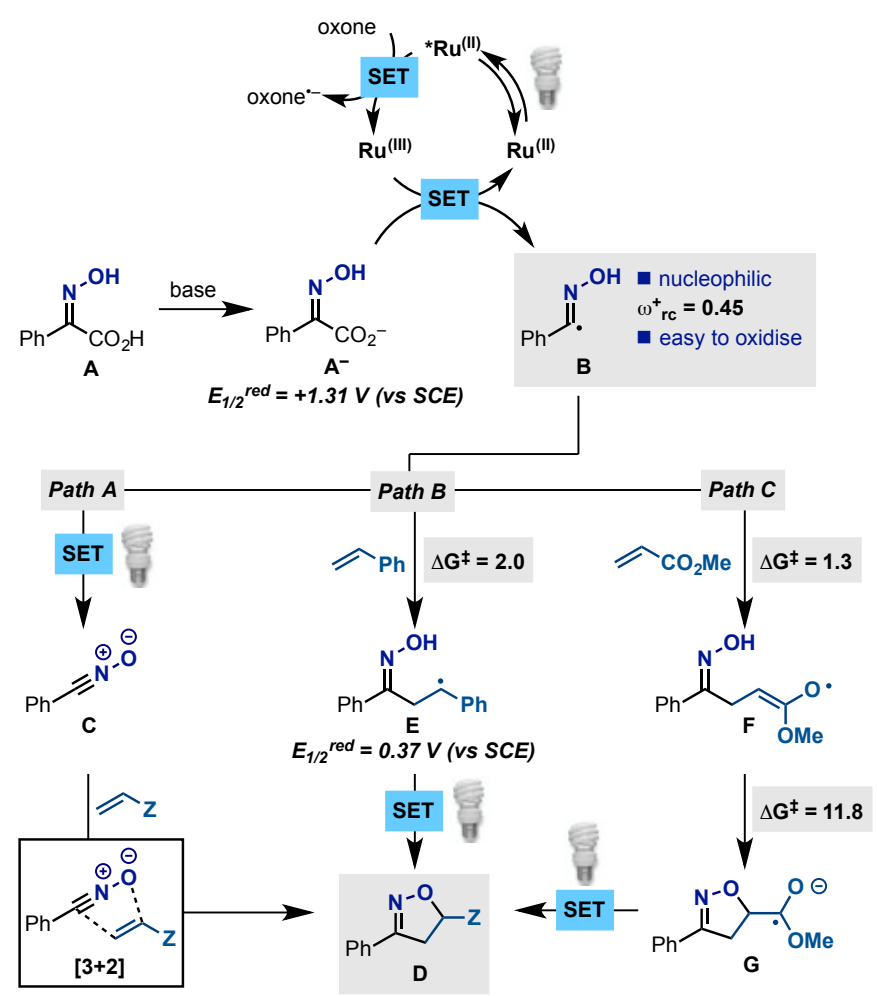

Scheme 4. Mechanistic pathways. DFT method: UB3LYP/6-31+G(d,p). The $\Delta G \ddagger$ values are in $\mathrm{Kcal} / \mathrm{mol}$.

From radical B three possible pathways can be envisaged. An additional SET oxidation would form the nitrile oxide $\mathbf{C}$ that upon [3+2] cycloaddition would deliver D (Path A). The oxidation potentials of many acyl radicals have been determined and they fell well in the range accessible by ${ }^{*} \mathrm{Ru}(\mathrm{bpy})_{3}{ }^{2+}$ thus supporting this scenario. ${ }^{22}$ Alternatively, radical addition of $\mathbf{B}$ to the olefins (Pathways $B$ and $C$ ) could deliver intermediates $\mathbf{E}$ and $\mathbf{F}$. Indeed, DFT calculations revealed $\mathbf{B}$ to be an extremely nucleophilic radical (electrophilicity index ${ }^{23} \omega_{\mathrm{rc}}^{+}=0.45$ ) and the addition reaction to both styrene and methyl acrylate to be very facile $\left(\Delta \mathrm{G}^{\ddagger}=2.0\right.$ and $1.3 \mathrm{kcal} / \mathrm{mol}$ respectively). ${ }^{19}$ From radical $\mathrm{E}$, photoredox oxidation $^{24}$ would form a benzylic carbocation that upon cyclization would give $\mathbf{D}$. In the case of Michael acceptors (Path C), photoredox oxidation of $\mathbf{F}$ is unlikely, and therefore a direct cyclization might take place giving ketyl radical G (calculated $\Delta \mathrm{G}^{\ddagger}=11.8 \mathrm{kcal} / \mathrm{mol}$ ). ${ }^{19}$ Final photoredox oxidation would form D. ${ }^{25}$ In order to distinguish between these three Pathways, we performed Hammett analysis on the reaction between 1a and para-substituted styrenes. This study gave a V-shaped
Hammett plot that is consistent with the reaction going trough

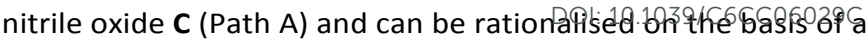
switch in frontier molecular orbitals interactions in the cycloaddition step going from electron rich to electron poor styrenes. ${ }^{26}$

In conclusion, we have developed the first visible lightmediated process that enables the generation of nitrile oxides and the easy synthesis of biologically relevant isoxazolines and isoxazoles. Future work will be aimed at expanding this double-oxidative approach to the generation of other dipoles. D. L. thanks the European Union for a Career Integration Grant (PCIG13-GA-2013-631556), Unesco-IUPAC-PhosAgro for a research grant (4500284613) and the School of Chemistry at the University of Manchester for generous support. W. Z. thanks the BBSRC for financial support.

\section{Notes and references}

¥ Footnotes relating to the main text should appear here. These might include comments relevant to but not central to the matter under discussion, limited experimental and spectral data, and crystallographic data.

1. M. E. Welsch, S. A. Snyder and B. R. Stockwell, Curr. Opin. Chem. Biol., 2010, 14, 347.

2. (a) L. Brunton, B. A. Chabner and B. Knollman, Goodman and Gilman's The Pharmacological Basis of Therapeutics, 2011, 12th edn., McGraw Hill, New York; (b) K. A. Kumar, M. Govindaraju, N. Renuka and G. V. Kumar, J. Chem. Pharm. Res., 2015, 7, 250; (c) F. Hu and M. Szostak, Adv. Synth. Catal., 2015, 357, 2583; (d) J. Sperry and B. Wright, Curr. Opin. Drug. Discov. Devel., 2005, 8, 723.

3. (a) P. G. Baraldi, A. Barco, S. Benetti, G. P. Pollini and D. Simon, Synthesis, 1987, 857; (b) M. G. Charest, C. D. Lerner, J. D. Brubaker, D. R. Siegel and A. G. Myers, Science, 2005, 308, 395; (c) J. H. Frederich and P. G. Harran, J. Am. Chem. Soc., 2013, 135, 3788.

4. (a) T. M. V. P. e. Melo, Curr. Org. Chem., 2005, 9, 925; (b) M. W. Davies, R. A. J. Wybrow, C. N. Johnson and J. P. A. Harrity, Chem. Commun., 2001, 1558; (c) J. E. Moore, M. W. Davies, K. M. Goodenough, R. A. J. Wybrow, M. York, C. N. Johnson and J. P. A. Harrity, Tetrahedron, 2005, 61, 6707; (d) F. Himo, T. Lovell, R. Hilgraf, V. V. Rostovtsev, L. Noodleman, K. B. Sharpless and V. V. Fokin, J. Am. Chem. Soc., 2005, 127, 210; (e) C. Spiteri, P. Sharma, F. Zhang, S. J. F. Macdonald, S. Keeling and J. E. Moses, Chem. Commun. , 2010, 46, 1272; (f) C. Spiteri, C. Mason, F. Zhang, D. J. Ritson, P. Sharma, S. Keeling and J. E. Moses, Org. Biomol. Chem., 2010, 8, 2537; (g) J. A. Crossley and D. L. Browne, J. Org. Chem., 2010, 75, 5414; (h) J. A. Crossley and D. L. Browne, Tetrahedron Lett., 2010, 51, 2271; (i) J.S. Poh, C. Garcia-Ruiz, A. Zuniga, F. Meroni, D. C. Blakemore, D. L. Browne and S. V. Ley, Org. Biomol. Chem., 2016, 14, 5983.

5. (a) F. Heaney, Eur. J. Org. Chem., 2012, 3043; (b) T. M. V. D. P. e. Melo, Eur. J. Org. Chem., 2010, 3363.

6. (a) S. Minakata, S. Okumura, T. Nagamachi and Y. Takeda, Org. Lett., 2011, 13, 2966; (b) J. P. Waldo and R. C. Larock, Org. Lett., 2005, 7, 5203; (c) N. Arai, M. Iwakoshi, K. Tanabe and K. Narasaka, Bull. Chem. Soc. Jpn., 1999, 72, 2277. 
7. A. Studer and D. P. Curran, Angew. Chem. Int. Ed., 2015, $55,58$.

8. (a) C. K. Prier, D. A. Rankic and D. W. C. MacMillan, Chem. Rev., 2013, 113, 5322; (b) N. A. Romero and D. A. Nicewicz, Chem. Rev., 2016, DOI: 10.1021/acs.chemrev.1026b00057; (c) J. J. Douglas, M. J. Sevrin and C. R. J. Stephenson, Org. Process. Res. Dev., 2016, DOI: 10.1021/acs.oprd.1026b00125.

9. (a) X.-Q. Hu, J.-R. Chen, Q. Wei, F.-L. Liu, Q.-H. Deng, A. M Beauchemin and W.-J. Xiao, Angew. Chem. Int. Ed., 2014, 53, 12163; (b) C. L. Cavanaugh and D. A. Nicewicz, Org. Lett., 2015, 17, 6082; (c) P. D. Morse and D. A. Nicewicz, Chem. Sci., 2015, 6, 270; (d) D. C. Miller, G. J. Choi, H. S. Orbe and R. R. Knowles, J. Am. Chem. Soc., 2015, 137, 13492; (e) A. J. Musacchio, L. Q. Nguyen, H. Beard and R. R. Knowles, J. Am. Chem. Soc., 2014, 136, 12217; (f) D. P. Hari, T. Hering and B. Konig, Org. Lett., 2012, 14, 5334; (g) A. Das, I. Ghosh and B. Konig, Chem. Commun., DOI: 10.1039/c1036cc04366f.

10. J. Xuan, L.-Q. Lu, J.-R. Chen and W.-J. Xiao, Eur. J. Org. Chem., 2013, 6755.

11. (a) J. Xuan, X.-D. Xia, T.-T. Zeng, Z.-J. Feng, J.-R. Chen, L.-Q. Lu and W.-J. Xiao, Angew. Chem. Int. Ed., 2014, 53, 5653;

(b) T.-T. Zheng, J. Xuan, W. Ding, K. Wang, L.-Q. Lu and W.J. Xiao, Org. Lett., 2015, 17, 4070; (c) Q.-H. Deng, W.-Q. Zou, L.-Q. Lu, Z.-L. Tang, J.-R. Chen and W.-J. Xiao, Chem. Asian. J., 2014, 9, 2432.

12. (a) C. Vila, J. Lau and M. Rueping, Beilstein J. Org. Chem., 2014, 10, 1233; (b) M. Rueping, D. Leonori and T. Poisson, Chem. Commun., 2011, 47, 9615.

13. Y.-Q. Zou, L.-Q. Lu, L. Fu, N.-J. Chang, J. Rong, J.-R. Chen and W.-J. Xiao, Angew. Chem. Int. Ed., 2011, 123, 7309.

14. (a) T. R. Blum, Y. Zhu, S. A. Nordeen and T. P. Yoon, Angew. Chem. Int. Ed., 2014, 53, 11056; (b) Z. Lu, M. Shen and T. P. Yoon, J. Am. Chem. Soc., 2011, 133, 1162.

15. L. Chen, C. S. Chao, Y. Pan, S. Dong, Y. C. Teo, J. Wang and C.-H. Tan, Org. Biomol. Chem., 2013, 11, 5922.

16. T. P. Nicholls, G. E. Constable, J. C. Robertson, M. G. Gardiner and A. C. Bissember, ACS Catal., 2016, 6, 451.

17. Z. Liang, S. Xu, W. Tian and R. Hang, J. Org. Chem., 2015, $11,425$.

18. (a) J. Xuan, Z.-G. Zhang and W.-J. Xiao, Angew. Chem. Int. Ed., 2015, 54, 15632; (b) G. Bergonzini, C. Cassani and C.-J. Wallentin, Angew. Chem. Int. Ed., 2015, 54, 14066; (c) J. Liu, Q. Liu, H. Yi, C. Qin, R. Bai, X. Qi, Y. Lan and A. Lei, Angew. Chem. Int. Ed., 2014, 53, 502; (d) H. Huang, G. Zhang and Y. Chen, Angew. Chem. Int. Ed., 2015, 54, 7872; (e) H. Tan, H. Li, W. Ji and L. Wang, Angew. Chem. Int. Ed., $2015,54,8374$.

19. See SI for more information.

20. A. Noble and D. W. C. MacMillan, J. Am. Chem. Soc., 2014, 136, 11602.

21. J. W. Tucker, J. M. R. Narayanam, P. S. Shah and C. R. J. Stephenson, Chem. Commun., 2011, 47, 5040.

22. (a) M. Majek and A. J. v. Wangelin, Angew. Chem. Int. Ed., 2015, 54, 2270; (b) W. Guo, L.-Q. Lu, Y. Wang, Y.-N. Wang, J.-R. Chen and W.-J. Xiao, Angew. Chem. Int. Ed., 2015, 54, 2265; (c) The SET oxidation of the acyl radical can also be performed by oxone.

23. F. D. Vleeschouwer, V. V. Speybroeck, M. Waroquier, P. Geerlings and F. D. Proft, Org. Lett., 2007, 9, 2721.
D. D. M. Wayner, D. J. McPhee and D. Griller , Am $_{\text {ive }}$ Cheme Soc., 1988, 110, 132. DOI: 10.1039/C6CC06029C

25. Y. Roh, H.-Y. Jang, V. Lynch, N. L. Bauld and M. J. Krische, Org. Lett., 2002, 4, 611.

26. (a) A. Dondoni, Tetrahedron Lett., 1967, 8, 2397; (b) L. Toma, P. Quadrelli, G. Perrini, R. Gandolfi, C. D. Valentin, A. Corsaro and P. Caramella, Tetrahedron, 2000, 56, 4299. 